\title{
Human Weakness in Isaac of Nineveh and the Syriac Macarian Corpus: A first Investigation
}

\begin{abstract}
This paper explores some ideas of the Syriac Macarian corpus which influenced Isaac of Nineveh's conception of what he calls 'weakness', a condition which, for him, indicates an original frailty inscribed in creaturality. Three concepts deriving from different Macarian writings are analysed and placed side by side with some reflections of Isaac: the idea of 'weakness' as something proper to the human condition; the relationship to negative experiences and to God in order to discover its reality; and the link between acknowledging it and humility. Through this comparison, Isaac's debt to the 'Syriac Macarius' emerges. The fact that Isaac read texts coming from different authors and proper to the Syriac version which is different from the Greek Pseudo-Macarian corpus - attributing them to the Egyptian ascetic 'Macarius', is underlined. This highlights Isaac's distinctive approach to the texts and points to the necessity of studying the Syriac versions independently from their Greek originals.
\end{abstract}

\section{Keywords}

Isaac of Nineveh; Syriac Macarian corpus; Syriac spirituality; human weakness

Isaac of Nineveh, a solitary of the $7^{\text {th }}$ century, belonged to the Church of the East. ${ }^{1} \mathrm{He}$ is the best known among those monastic writers who, between the $7^{\text {th }}$ and $8^{\text {th }}$ centuries, gave birth to a real blossoming of East-Syrian spirituality. ${ }^{2}$ Three Collections of his homilies have been handed down to us, the first of which was translated from Syriac into Greek by the $9^{\text {th }}$ century, at the Chalcedonian monastery of Mar Saba, in Palestine. ${ }^{3}$ It is especially thanks to this translation that part of Isaac's writings was translated into other languages. As a

\footnotetext{
${ }^{1}$ For Isaac and his works, see S. Chialà, Dall'ascesi eremitica alla misericordia infinita. Ricerche su Isacco di Ninive e la sua fortuna (Florence: Olschki, 2002); H. Alfeyev, The Spiritual World of Isaac the Syrian (Kalamazoo-Spencer: Cistercian Publications, 2000).

${ }^{2}$ For these writers, see R. Beulay, La lumière sans forme (Chevetogne: Éditions de Chevetogne, 1987); S. Brock, Spirituality in the Syriac Tradition (Moran Etho, 2, Kottayam: SEERI, 1989) pp. 12-16; 31-36; P. Bettiolo, 'Letteratura siriaca', in A. Di Bernardino (ed.), Patrologia, vol. V (Genoa-Milan: Marietti, 2005) pp. 479-490.

${ }^{3}$ See S. Brock, 'From Qatar to Tokyo, by Way of Mar Saba: the Translations of Isaac of Beth Qatiraye (Isaac the Syrian)', Aram 11-12 (1999-2000), pp. 475-484 (476-477); idem, 'Syriac into Greek at Mar Saba: the Translation of St. Isaac the Syrian', in J. Patrich (ed.), The Sabaite Heritage in the Orthodox Church from the Fifth Century to the Present (Orientalia Lovaniensia Analecta, 98, Leuven: Peeters, 2001) pp. 201-208.
} 
consequence, his ideas deeply influenced the Christian spiritual tradition, crossing dogmatic and geographical boundaries. ${ }^{4}$

'Pseudo-Macarius', an anonymous spiritual writer from Mesopotamia or Asia Minor, lived long before Isaac, between the end of the $4^{\text {th }}$ and the beginning of the $5^{\text {th }}$ century. ${ }^{5} \mathrm{He}$ wrote in Greek, and about a century later, some of his writings were circulating in a Syriac translation. His Greek corpus of writings, which greatly influenced both Eastern and Western Christian spirituality, was generally attributed to the Egyptian monk Macarius the Great, the $4^{\text {th }}$-century founder of the monastic settlement of Scetis. ${ }^{6}$ Also the Syriac version of the Macarian writings was influential in East-Syrian milieus: as Beulay pointed out, PseudoMacarius inspired the East-Syriac monastic writers of the $7^{\text {th }}$ and $8^{\text {th }}$ centuries as much as Evagrius did. ${ }^{7}$ The Syriac Macarian corpus, however, is remarkably different from the Greek one, and includes not only writings of Pseudo-Macarius, but also writings of other provenance.

One of Isaac's distinctive ideas is his conception of human weakness. ${ }^{8}$ The word he most often employs to describe it is rhalews (mhilutā), a term which we will encounter also

\footnotetext{
${ }^{4}$ See Brock, 'From Qatar to Tokyo', pp. 478-480, 484; idem, 'Crossing the Boundaries: an ecumenical Role played by Syriac monastic Literature', in M. Bielawski and D. Hombergen (eds.), Il monachesimo tra eredità e aperture (Studia Anselmiana, 140, Roma: Pontificio Ateneo S. Anselmo, 2004) pp. 221-238 (221-227); Chialà, Dall'ascesi, pp. 286-306, 325-364.

${ }^{5}$ For an introduction to Pseudo-Macarius, see V. Desprez, 'Macaire', in Dictionnaire de spiritualité, ascétique et mystique, doctrine et histoire. Tome 10 (Paris: Beauchesne, 1980), cols. 20-27; 39-43; M. Canévet, 'Macaire', in Dictionnaire de spiritualité. Tome 10, cols. 27-38.

${ }^{6}$ For an overview on Macarius the Egyptian, see A. Guillaumont, 'Macaire l'Égyptien', in Dictionnaire de spiritualité. Tome 10, cols. 11-13. His authorship was rejected by modern scholars after Villecourt listed similarities between the Pseudo-Macarian writings and condemned Messalian passages: see L. Villecourt, 'La date et l'origine des "Homélies spirituelles" attribuées à Macaire', Comptes rendus des séances de l'Académie des Inscriptions et Belles-Lettres 64.3 (1920), pp. 250-258. For the relationships between these writings and Messalianism, see Desprez, 'Macaire', in Dictionnaire de spiritualité. Tome 10, cols. 23-25, 27; H. Dörries, Symeon von Mesopotamien. Die Überlieferung der messalianichen 'Makarios'-Schriften (TU, 55.1, Leipzig: Hinrichs, 1941), where Dörries proposes, as author of the Pseudo-Macarian corpus, Symeon of Mesopotamia, a Messalian leader; C. Stewart, 'Working the Earth of the Heart'. The Messalian Controversy in History, Texts, and Language to AD 431 (Oxford: Clarendon Press, 1991), where the author convincingly argues for a Syriac background of the Greek corpus, through an analysis of its language and imagery.

${ }^{7}$ Beulay, La lumière sans forme, p. 35. For Pseudo-Macarius' influence, see pp. 35-94.

${ }^{8}$ On this theme, see Chialà, Dall'ascesi, pp. 158-160, where the author emphasises the importance, for Isaac, of the acknowledgement of 'weakness', and the link between this and humility. See also Louf's introduction to his translation of Isaac's 'Second Part', where he describes how, for Isaac, 'weakness' is revealed in the midst of 'temptations' and 'solitude' and stresses the fact that becoming aware of one's 'weakness' gives birth to
} 
in 'Macarius'. ${ }^{9}$ It literally indicates a lack of strength, a condition of feebleness which Isaac also describes with other expressions. ${ }^{10}$ As will become clear in the course of this article, Isaac does not conceive of 'weakness' as a passive attitude, as a state of worthlessness, which would ultimately deprive the creature of his dignity. Instead, for him, it coincides with a frailty proper to the human condition, whose meaning the person needs to discern, since it is thanks to its experience that the person can discover his highest dignity.

This article aims to explore some concepts of the Syriac Macarian corpus which influenced Isaac's understanding of human weakness. This survey does not pretend to be exhaustive: I will just point to some echoes of 'Macarius' in Isaac, which deserve to be studied in further depth. I examined three writings of the Syriac Macarian corpus, selecting some passages which will allow us to approach three themes that are essential in Isaac: the understanding of 'weakness' as the fact of being a human; the role of the relationship to God and to negative experiences in becoming aware of it; and the connection between the acknowledgement of one's weakness and humility. These passages will be placed side by side with a few of Isaac's reflections. The investigation of these topics will also provide the opportunity to explore a case of the influence of ascetical writings originally written in Greek on a Syriac author, and the way he read them.

The Syriac Macarian corpus is considerably smaller than the Greek one, yet also includes writings which are not found in it: the letters of 'the Egyptian', in particular, which

humility: A. Louf, Isaac le Syrien. Oeuvres Spirituelles - II (Bégrolles en Mauges: Abbaye de Bellefontaine, 2003) pp. 25-26, 33, 56-57. For an approach to the theme of weakness and suffering in Isaac, see my 'Human Frailty and Vulnerability in Isaac the Syrian', forthcoming in Studia Patristica.

${ }^{9}$ It is not the purpose of this article to discuss the origin of the different writings of the Syriac Macarian corpus and to identify their original authors, but to explore Isaac's use of them. It appears that for him, these writings and the Apophthegmata he quotes in his works (see note 24), were all produced by the same person, 'Macarius'. Therefore in this article I will avoid the term 'Pseudo-Macarius' and other possible designations in favour of simply 'Macarius', to point to the Syriac corpus as a unit. However, when the ancient tradition or modern scholars identified or proposed a particular author, I have mentioned it.

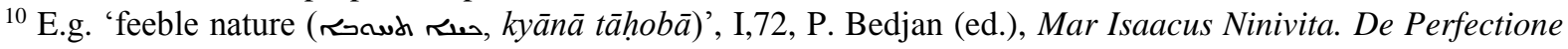
Religiosa (Paris-Leipzig: Harrassowitz, 1909) p. 499 (hereafter: Bedjan); 'weak nature (๔.ai rw, kyānāa rapyā)', III,7,38, S. Chialà (ed.), Isacco di Ninive. Terza collezione (CSCO, 637-638, Scr. Syri, 246-247,

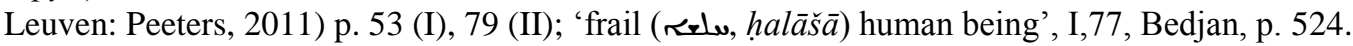


might be connected to the figure of the real Macarius of Egypt. ${ }^{11}$ Two different versions survive. The first is older ${ }^{12}$ and is attested in many manuscripts, ${ }^{13}$ the earliest of which dates back to $534 .{ }^{14}$ These writings are usually attributed simply to 'Macarius', without further description, but from the $8^{\text {th }}$ century onwards, some of them were ascribed to Macarius the Egyptian and some others to Macarius the Alexandrian, ${ }^{15}$ the priest of Kellia, another renowned $4^{\text {th }}$-century figure of the Egyptian desert. ${ }^{16}$ Strothmann, who edited the Syriac text, classified them according to the manuscript where these two attributions appear for the first time, ${ }^{17}$ and he listed 3 homilies and 8 letters of the Egyptian, and 3 homilies and 9 letters of the Alexandrian. ${ }^{18}$ The second Syriac version is independent, ${ }^{19}$ and is attested only in one $10^{\text {th }}$

\footnotetext{
${ }^{11}$ See Dörries, Symeon, pp. 378-389, for whom letters 2-8 'of the Egyptian' were not written by the same author as the rest of the corpus; W. Strothmann, 'Die erste Homilie des Alexandriners Makarios', in W. Strothmann (ed.), Makarios-Symposium über das Böse (Göttinger Orientforschungen, Syriaca, 24, Wiesbaden: Harrassowitz, 1983) pp. 99-108 (99), for whom also the first letter is of another author: idem, (ed.) Die Syrische Überlieferung der Schriften des Makarios, 2 vols (Göttinger Orientforschungen, Syriaca, 21, Wiesbaden: Harrassowitz, 1981), II, XXV (hereafter: Strothmann, I or II). Until recently, apart from the first letter (see below), and the third (partially corresponding to a writing of Ammonas in one manuscript: see F. Nau [ed.], Ammonas, successeur de saint Antoine. Textes grecs et syriaques [PO, 11.4, Paris: Firmin-Didot, 1915] pp. 484486), these letters were not known in their original language, and the Syriac version was the only witness including all of them. Thanks to Géhin's research, we are now aware of the existence of a Greek manuscript $\left(12^{\text {th }}\right.$ century) where the letters 'of the Egyptian', with the exception of 'Letter 4', are preserved: for their analysis and edition, see P. Géhin, 'Le dossier macarien de l'Atheniensis gr. 2492', Recherches Augustiniennes at Patristiques 31 (1999), pp. 89-147. Géhin's analysis of these letters shows their differences from the 'PseudoMacarian' writings: though not attributing them to the historical Macarius of Egypt, Géhin highlights their links to the 'Egyptian' milieu (Scetis) and to the tradition of the Apophthegmata, and does not exclude the possibility that they might convey something of Macarius the Egyptian's original teaching. They might have been written by a $5^{\text {th }}$-century monk, who gave shape to pre-existent 'Macarian material'. Rubenson, more recently, wrote that the first two letters might have been written by Macarius: see S. Rubenson, 'Argument and Authority in early monastic Correspondence', in A. Camplani and G. Filoramo (eds.), Foundations of Power and Conflicts of Authority in Late-Antique Monasticism (Orientalia Lovaniensia Analecta, 157, Leuven-Paris-Dudley: Peeters, 2007) pp. 75-87 (78-79).

${ }^{12}$ See Strothmann, I, IX; Stewart, Working the earth, p. 159.

${ }^{13}$ See Strothmann, I, X-XIV.

${ }^{14}$ BL Add 12,175. See W. Wright, Catalogue of Syriac Manuscripts in the British Museum acquired since the Year 1838, Part II (London, 1871), cols. 633-638 (Wr. 727). Already in this manuscript all the letters 'of the Egyptian' are included.

${ }^{15}$ For an overview on Macarius the Alexandrian, see A. Guillaumont, 'Macaire d'Alexandrie', in Dictionnaire de spiritualité. Tome 10, cols 4-5.

${ }^{16}$ A confusion between the two 'Macarius' often appears in ancient sources. See A. Guillaumont, 'Le problème des deux Macaire dans les Apophthegmata Patrum', Irénikon 48 (1975), pp. 41-59.

${ }^{17}$ Vat. Syr. 122, of 769. See S.E. Assemani and J.S. Assemani, Bibliothecae Apostolicae Vaticanae codicum manoscriptorum catalogus, vol. 3 (Rome, 1759) pp. 132-139.

${ }^{18}$ See Strothmann, I, IX.

${ }^{19}$ See Strothmann, I, X. For the material included in both translations, see Strothmann, I, XXIII.
} 
century manuscript. ${ }^{20}$ However, the fact that Isaac clearly quotes from the first version ${ }^{21}$ led me to focus on this alone.

Even from this partial survey, it will be noticed that the Syriac translator(s) mediated and reworked the original Greek corpus. They combined different Greek passages ${ }^{22}$ and added new material, so that while the Syriac version is indeed based on the Greek corpus, it has also been reshaped into a new literary text. ${ }^{23}$ This nature of the Syriac version raises many issues, which cannot be dealt with here, first of all whether we can describe it simply as a 'translation' or if we should conceptualize it differently. One point should, however, be kept in mind: Isaac, who mentions writings ascribed to both the Egyptian and the Alexandrian in Strothmann's classification, considers their author to be one and the same person, 'the blessed Macarius', ${ }^{24}$ an ascetic of the Egyptian desert, a solitary who faced problems similar to his own.

I wish to begin this analysis from a passage taken from the so-called ' 7 th letter of Macarius the Egyptian', which does not appear in the Greek Macarian corpus, but is part of the Syriac one. ${ }^{25}$ Isaac does not quote this passage directly. Dadišo' however, a contemporary of Isaac - he also from Beth Qațraye and linked, as Isaac, to the monastery of Rabban Shabur

\footnotetext{
${ }^{20}$ Sin. Syr. 14. See A. Smith Lewis, Catalogue of the Syriac mss. in the Convent of St. Catharine on Mount Sinai (Studia Sinaitica, 1, London: Cambridge University Press, 1894) p. 17. This manuscript, a Chalcedonian monastic anthology, includes also extracts from Isaac's works. See Brock, 'Crossing the boundaries', pp. 225, 234-235.

${ }^{21}$ Isaac quotes Al h 1,3 (first version) instead of Sin 7,2 (second version). Moreover, the letters of 'the Egyptian' do not appear in Sin. Syr. 14. In this article, I will refer to the Macarian writings using Strothmann's abbreviations.

${ }^{22}$ See Strothmann, II, XLII-XLIV.

${ }^{23}$ See Beulay, La lumière sans forme, pp. 40-42.

${ }^{24}$ See I,72, Bedjan, p. 495. Isaac never explicitly quotes 'the Alexandrian' in his writings, while he mentions Macarius the Great $(\mathrm{I}, 81)$. Then it is highly probable that all the other mentions of a 'Macarius' in his corpus were intended to refer to 'the Egyptian'. See I,41 and I,80, Bedjan, p. 310, 563, cf. E.A.W. Budge, The Book of Paradise, being the Histories and Sayings of the Monks and Ascetics of the Egyptian Desert by Palladius, Hieronymus and Others (London, 1904), 53, p. 605 (I); 446 (II); I,60, Bedjan, p. 422, cf. Budge, 46 [668], p. 829 (I); 630 (II); I,81, Bedjan, p. 569, cf. Budge, 395, p. 721 (I); 543 (II); II,14,21, S. Brock (ed.), Isaac of Nineveh (Isaac the Syrian). 'The Second Part', Chapters IV-XLI (CSCO, 554-555, Scr. Syri, 224-225, Leuven: Peeters, 1995) p. 62 (I); 73 (II), cf. Budge, 338 [344], p. 915 (I); $702-703$ (II); III,4,10, Chialà, Isacco di Ninive, p. 21 (I); 35 (II), an apophthegm which is not found in Budge's edition of 'Ananišo"s work, and corresponds to Macarius the Egyptian 19 in the Alphabetical Series (PG 65, col. 269).

${ }^{25}$ Strothmann argued that it was originally written in Greek, as all the letters 'of the Egyptian'. See Strothmann, II, XII-XV. This is now confirmed by Géhin's discovery: see Géhin, 'Le dossier macarien', pp. 89-147, and footnote 11 .
} 
- quotes it in his writing 'On Solitude'. ${ }^{26}$ This might also suggest that Isaac had access to this text. The passage reads as follows: 'Many times we are abandoned (_roser, meštabqinan), so that we might know our weakness ( dadews s.x, d-nedda' mhilutan), that we are human

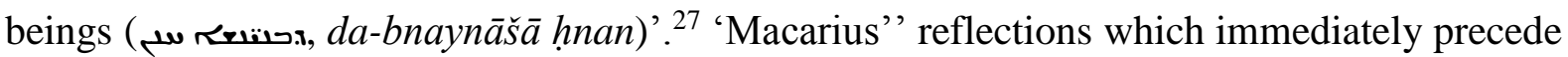
this passage deal with spiritual struggle, which he conceives as arduous and demanding. In the midst of it, apparently without reason, the person can be 'abandoned' by God, an event whose meaning is, possibly, better conveyed by another translation of the verb used, (eštbeq): 'to be left to oneself'. The aim of God's 'abandonment', or 'leave', is to hand the person over to the experience of his 'weakness': through it, one comes to know one's weakness, where the verb 'to know', $2\left(y d^{\prime}\right)$, does not convey the idea of a simple intellectual knowledge, but, in Syriac, it points simultaneously to 'knowledge', 'perception', 'understanding', and 'awareness', to a global experience which touches all the dimensions of the created being. Concerning this 'weakness' 'Macarius' does not say much, but he makes a brief and clear statement: it coincides with the fact of being a human.

The second passage is selected from a Macarian writing which might really go back to one of the two 'Macarius'. This writing is extant in Greek $^{28}$ but not as part of the Greek corpus, and is explicitly mentioned and ascribed to 'Macarius' in Isaac's Homily I, $72 .{ }^{29}$ It is the so-called epistle Ad Filios Dei ${ }^{30}$ which Gennadius, in the $5^{\text {th }}$ century, already attributed to

\footnotetext{
${ }^{26}$ Dadišo's quotation has been pointed out by Beulay and Strothmann. See Beulay, La lumière sans forme, $\mathrm{p}$. 36; Strothmann, I, XXII. This passage can be read in A. Mingana, Woodbrooke Studies, vol. VII (Cambridge: Heffer and Sons, 1934) p. 238 col. 2 (Syr.), 129 (ET); for a critical edition, see F. del Rio Sanchez (ed.), Los

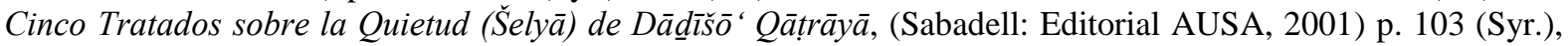
156 (ST).

${ }^{27}$ Aeg ep 7,5, Strothmann, I, p. 122.

${ }^{28}$ This writing is also extant in Latin, Armenian, and partially in Coptic. See Guillaumont, 'Macaire l'Égyptien', in Dictionnaire de spiritualité. Tome 10, col. 12. The Greek text was edited by Strothmann (Strothmann, II, XVIXXII). On the Syriac version, see G.L. Marriott, 'Macarius of Egypt: his Epistle Ad Filios Dei in Syriac', JTS 20 (1918), pp. 42-44.

${ }^{29}$ See Bedjan, p. 500. Isaac's mentioning of Aeg ep 1 has been pointed out by Marriott, Strothmann and Beulay. See G.L. Marriott, 'Isaac of Nineveh and the Writings of Macarius of Egypt', JTS 20 (1919), pp. 345-347 (346); Strothmann, II, XV-XVI; Beulay, La lumière sans forme, pp. 36-37; 39.

${ }^{30}$ For a reflection on this text, see P. Bettiolo, 'Il giogo del Paraclito. Nota di lettura e testo della "Lettera ai figli" di Macario l'egiziano', in B. Bocchini Camaiani and A. Scattigno (eds.), Anima e paura. Studi in onore di
} 
Macarius the Egyptian. ${ }^{31}$ The whole letter describes ascetic life as the alternation of God's aid and of different temptations, through which God 'puts to the test' ${ }^{32}$ the person in order to prove his heart. In this context, 'Macarius' introduces the concept of 'weakness', not using the word mhilutā, but the idea of 'being weakened' by the growing pressure of temptations. He writes:

If the heart is frightened by these things, so as to be weakened (misd, netkrah) by the toils of these wars, then the merciful God sends to it a holy power (w.w hayla qaddiš $\bar{a}$ ) and He sustains the heart (...). Then, when the good God sees that the heart has been strengthened against the enemy, He takes away [his] power from it from time to time, and He permits that the enemies might be sent forth to fight against it (...). Just as a ship without rudders goes off course and strikes here and there, so also the heart when is weakened and grows feeble through these things. [But] the good God who takes care of his creature sends again [his] holy power and He sustains his heart (...) [placing it] under the yoke of the Paraclete. (...) Then the good God begins to open the eyes of his heart, so that he might know that He is his supporter. Then the person comes to know how to honour God with great humility (محصح, $m u k k \bar{a} k \bar{a}) .{ }^{33}$

\footnotetext{
Michele Ranchetti (Macerata: Quodlibet, 1998) pp. 171-180; for a perspective on 'weakness' seen in the light of the relationship between human effort and grace, see Louf's introduction to his French translation of the Greek and Latin text: B. Outtier, A. Louf, M. van Parys and A. Zirnheld, Lettres des Pères du désert (Spiritualité orientale, 42, Bégrolles-en-Mauges: Abbaye de Bellefontaine, 1985) pp. 68-71.

${ }^{31}$ See E. C. Richardson (ed.), Hieronymus, Liber de viris inlustribus. Gennadius, Liber de viris inlustribus (TU, 14.1a, Leipzig: Hinrichs, 1896) p. 64. See also G.L. Marriott, 'Gennadius of Marseilles on Macarius of Egypt', JTS 20 (1919), pp. 347-349. Marriott and Wilmart, in modern times, considered the letter authentic, Guillaumont thought this was a possibility, and Rubenson regards this as probable (see footnote 11). See Marriott, 'Macarius of Egypt', pp. 42-44; A. Wilmart, 'La lettre spirituelle de l'abbé Macaire', Revue d'Ascetique et Mystique 1 (1920), pp. 58-83 (60-66); Guillaumont, 'Macaire l'Égyptien', in Dictionnaire de spiritualité. Tome 10, col. 12; Rubenson, 'Argument and Authority', pp. 78-79. For the position of Géhin, for whom the letter might bear traces of Macarius' teachings, but cannot have been written by him, see Géhin, 'Le dossier macarien', pp. 89-147, and footnote 11.

${ }^{32}$ Aeg ep 1,4, Strothmann, I, p. 76; II, 50.

${ }^{33}$ Aeg ep 1,9-12, Strothmann, I, pp. 79-81; II, 52-54.
} 
The inner dynamic which 'Macarius' describes here sees the person engaged in a relationship with two realities: the negative forces which press upon him, and God. Between these two poles, the experience of weakness emerges, again, as the true reality of the creature, who can be frightened, frail, radically lost. God, through a reiterated alternation of his proximity and distancing, leads the person to experience his weakness in contact with negative factors, which have therefore the role of making this experience possible. It is only after the creature has passed through the experience of weakness that God supports the heart with his 'power' - that waylā) which, reminiscent of the words of Luke in the account of the Annunciation, ${ }^{34}$ 'Macarius' seems to identify with the Holy Spirit. Only after having tasted the experience of weakness does the human being become able to recognize God as 'his supporter', as 'other' from the creature, who acknowledging this becomes truly humble.

Let us come to Isaac now. I will mainly focus on three of his Centuries, ${ }^{35}$ which should be considered together. In the first he writes:

There is a certain power (New, haylā) with the human being, and whenever it journeys afar from him, immediately fear comes close to [his] heart, and [his] soul becomes weak (Nusds, metmahlāa) in all its spiritual members (...). And when it approaches again to him, that very moment the soul puts on courage and the heart becomes stronger than a mountain, and it is not afraid of anything in creation. ${ }^{36}$

We see, here, how Isaac's words evoke those of 'Macarius'. He speaks of a rev (haylā) which draws near and journeys afar from the person, who, as a consequence, experiences strength and lack of strength, i.e. his weakness. In the second Century, Isaac

\footnotetext{
${ }^{34}$ See Lk. 1:35 (Pesh.).

35 The four Centuries on spiritual knowledge are the third chapter of Isaac's Second Part. They are unedited. The only manuscript which contains the whole Second Part to be almost complete is syr. e. 7 (Bodleian Library, Oxford), copied in the $10^{\text {th }}-11^{\text {th }}$ century. I consulted it for Isaac's quotations.

${ }^{36}$ Centuries II,61.
} 
states that this 'power' gave the martyrs and the ascetics the strength to overcome suffering

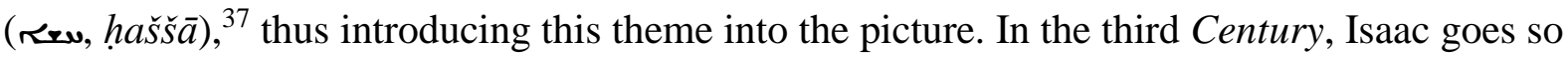
far as to say that the martyrs, because of God's power, were even made insensible to suffering in the midst of their torments. One of them, however, when his knee was slashed open, 'suffered (zw, haš) in this limb'. And when he was asked the reason for that, he answered with a reply that expressed the truth, for Isaac: 'I was abandoned in order to suffer

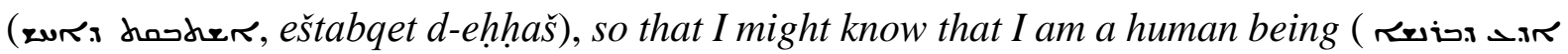
¡ until now' ${ }^{38}$ Here, Isaac uses the same verbs employed in the first Macarian quotation: Sotre (eštbeq), which refers to God's 'abandonment', ${ }^{39}$ and $(y d)$, which refers to the acknowledgement of being a human. Even if in Isaac's passage there is no direct mentioning of 'weakness' - already evoked, however, in the first Century -, the parallels with 'Macarius' are striking.

The main difference between the passage from 'Macarius' and Isaac is Isaac's mentioning of suffering: for him, between God's 'abandonment' and the acknowledgement of being a human stands the experience of suffering. It is the focus on this personal perception of suffering which characterises Isaac's reflection. This experience, which points to the core of subjective identity, ${ }^{40}$ leads the person to become conscious of his created weakness, and as

\footnotetext{
37 'I think that this was the power by which the blessed martyrs were victorious over the suffering of martyrdom (...). And by this [power] also the solitary fathers despised the great temptations of the demons', Centuries II,62.

${ }^{38}$ Centuries II,63.

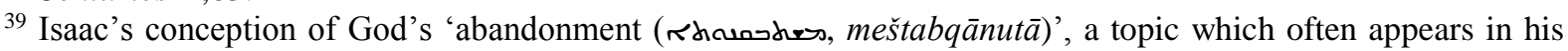
writings, shows similarities also with Evagrius' reflection. See Gnostikos 28 and notes in A. Guillaumont and C. Guillaumont (eds.), Évagre le Pontique. Le Gnostique ou à celui qui est devenu digne de la science (SC, 356, Paris: Les Éditions du Cerf, 1989) pp. 135-143; the theme appears also in the Lausiac History, with accents close to Isaac's, in the account of Paphnutius' answer to Palladius' and Evagrius' questions about the stumbling of advanced ascetics: see the Syriac version in Budge, The Book of Paradise, pp. 265-273 (I), 217-222 (II); see also J. Driscoll, 'Evagrius and Paphnutius on the Causes for Abandonment by God', Studia Monastica 39.2 (1997), pp. 259-286. On 'abandonment' in Isaac, see Alfeyev, The Spiritual World, pp. 101-109. I am analysing this theme for my DPhil dissertation.

${ }^{40}$ This is also emphasised by Isaac's use of the direct speech: the martyr narrates his story in the first person.
} 
a consequence, to the confession of the 'otherness' of God's (haylä), within the context of a relational dynamic similar to the one described in the second Macarian passage.

Isaac's stress on the role of suffering, though close to the Macarian intuition, introduces further complexity. While 'Macarius' describes an acknowledgement of weakness which takes place in contact with negative conditions, ${ }^{41}$ Isaac's words also explicitly highlight the impact of negativity on the person, thus raising the radical question of the meaning of suffering for human existence. Suffering then, is not a mute, senseless event for Isaac, but something which calls out to the person and questions him. ${ }^{42}$ As in the case of the martyr, its experience leads to the discovery of one's human frailty, and to its assumption before God, thus evoking one's responsibility for one's own created state.

As for 'Macarius', so also for Isaac this acknowledgement of weakness gives birth to humility, to be conceived as the state of the creature who, having passed through suffering, knows by experience the meaning of being a creature: '[The person] who is lacking the knowledge of his weakness (mbialeuss $r$ s., ida'ta da-mhiluteh) is lacking humility (Rhores, makkikutā)', ${ }^{43}$ Isaac states. As we can see, this humility and awareness of weakness are not passive states. On the contrary, they require a difficult labour of confrontation with suffering, and they point to the high dignity of the human being, who can stand before God in the reality of his frailty, and look at God as God, 'other' from himself.

The theme of humility allows us to move to the last Macarian passage, taken from the so-called 'first homily of Macarius the Alexandrian', quoted in Isaac's Homily I,72 and ascribed to 'Macarius'. ${ }^{44}$ While the rest of this text corresponds to different passages of the

\footnotetext{
41 These conditions are, also in 'Macarius', states of extreme difficulty, so that it can be said that also for 'Macarius' suffering plays a role in spiritual life. However, at least in the writings I analysed, there is no direct mention of a link between personal suffering and acknowledgement of weakness.

${ }^{42}$ I am studying this topic in Isaac's corpus for my DPhil.

${ }^{43} \mathrm{I}, 8$, Bedjan, p. 108.

44 This writing is attested for the first time in a $6^{\text {th }}$-century manuscript, BL Add 17,166, Wright, Catalogue of Syriac Manuscripts in the British Museum, Part II, cols. 658-660 (Wr. 737). For a discussion of this text, see Strothmann, 'Die erste Homilie', pp. 102-108. Marriott, Strothmann and Beulay identified Isaac's quotation,
} 
Greek corpus, this passage appears only in Syriac. ${ }^{45}$ Isaac calls this writing a 'letter', ${ }^{46}$ reflecting a tradition which appears only in two extant manuscripts of the Syriac corpus, ${ }^{47}$ both anthologies of monastic texts. Only one of them, however, BL Add 18,814, of the $9^{\text {th }}$ century, includes also both the other writings examined here, where they are, as in Isaac, simply attributed to 'Macarius', with no distinction between the Egyptian and the Alexandrian. From these elements one can hypothesise that, although Isaac cannot have read from this manuscript, given its late date, he might have had access to 'Macarius' in an earlier witness belonging to the same tradition. The fact that BL Add 18,814 has a West-Syrian origin does not stand against this hypothesis, because similar collections of monastic writings travelled, with modifications, between the different Church communities. ${ }^{48}$ Nevertheless, further study is needed to explore this issue.

In this Macarian passage there is no mention of human weakness. However, Isaac also links this passage to this theme. In his 'letter', 'Macarius' warns the ascetic against the danger of pride (Rhosi, rāmutā), which derives from the mistaken idea that, since one has received 'a little rest', one has reached perfection. ${ }^{49}$ Against this risk, he invites the person to

which partially, but not substantially, differs from the text of Strothmann's edition. See Marriott, 'Isaac of Nineveh', pp. 346-347; Strothmann, II, Xxx; Beulay, La lumière sans forme, p. 36, 39.

${ }^{45}$ It has a parallel, however, in the Arabic version: for this writing's structure, see Strothmann, II, XLII. Strothmann argues that the 14 sections of $\mathrm{Al} \mathrm{h} 1$ formed a unit already in Greek, so that also this passage would be authentically Pseudo-Macarian: see Strothmann, 'Die erste Homilie', pp. 105-106. This passage is also mentioned in Simon of TTaibuteh's unedited Homily on the Consecration of the Cell: see Beulay, La lumière sans forme, p. 204; P. Bettiolo, Simone di Taibuteh. Violenza e grazia. La coltura del cuore (Collana testi patristici, 102, Rome: Città Nuova, 1992) pp. 145-146. It also inspired John of Dalyatha: see Beulay, La lumière sans forme, p. 82; idem (ed.), La collection des lettres de Jean de Dalyatha, (PO, 39.3, Turnhout: Brepols, 1978) p. 404, 406 (Syr.); 405 (FT); N. Khayyat (ed.), Jean de Dalyatha. Les Homélies I-XV (Sources Syriaques, 2, Antélias-Hadat: CERO-UPA, 2007), p. 158 (Syr.), 159 (FT). I thank Mary Hansbury who mentioned these passages to me.

${ }^{46}$ Bedjan, p. 495.

${ }^{47}$ BL Add 14,582, Wright, Catalogue of Syriac Manuscripts in the British Museum, Part II, cols. 692-696 (Wr. 752), of 816, and BL 18,814, idem, Catalogue of Syriac Manuscripts in the British Museum, Part II, cols. 793796 (Wr. 797). See Strothmann, II, XXXI; idem, 'Die erste Homilie', pp. 106-107.

${ }^{48}$ Isaac's manuscript tradition itself bears witness to this process of communication, with the attestation of his writings' circulation among Chalcedonian and Syriac Orthodox. See Brock, 'Crossing the boundaries', pp. 222223. In this article, Brock brings also other examples of this circulation (John of Dalyatha, Philoxenus, Abraham of Nathpar, Maryrius/Sahdona and others).

${ }^{49}$ See Al h 1,2, Strothmann, I, p. 135-136; II, 88. 
become conscious of his condition of mutability, where experiences of grace and afflictions necessarily alternate. He writes:

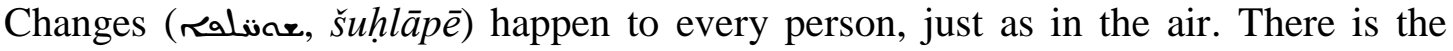
time of cold, and after a moment, heat, and perhaps hail, and after a little, fair weather. And [it is] thus for our instruction: [there is] war and the help of grace, and sometimes the soul is in a tempest, and violent waves assail it, and again, sometimes there is a change and it is visited by grace, and joy fills the heart (...). Therefore, if after these things chance-events which afflict us press hard, let us not become sad, and in the time of the rest which is from grace, let us not boast, but in the time of joy, let us contemplate affliction ( $\sim_{S}$ Jar, 'ulșānā) and in the time of affliction, let us wait for help. ${ }^{50}$

In his Homily I,72 Isaac, though sharing the whole Macarian reflection, focuses in particular on these conditions of 'affliction'. Through the demanding exercise of remembering them, one will avoid the danger of 'exaltation', which together with 'desperation' constitute the attitude contrary to humility. ${ }^{51}$ Isaac speaks of remembering 'the impure thoughts and dishonourable images which were firmly fixed in your mind in the time of tempest, the tumult and disorder of the thoughts that were assailing you (...) in a thick, deep darkness', ${ }^{52}$ 'the slippery paths [trodden] in the time of your abandonment' ${ }^{53}$ Briefly, he exhorts his reader to a memory of those states of suffering which have the role of making him

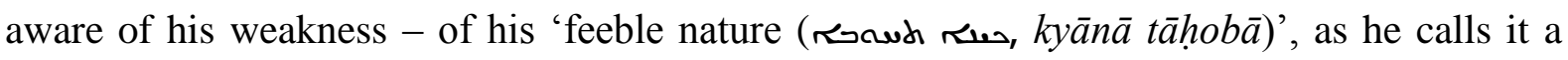

\footnotetext{
${ }^{50} \mathrm{Al}$ h 1,3, Strothmann, I, p. 137; II, 88-89.

${ }^{51}$ On these themes, see my initial article "“Changes happen to every Person, just as in the Air": an Analysis of the Theme of Humility in Isaac the Syrian's Homily I,72', forthcoming in The Harp, Review of Syriac, Ecumenical and Oriental Studies, SEERI, Kottayam (proceedings of the $8^{\text {th }}$ World Syriac Conference).

52 Bedjan, p. 498.

${ }^{53}$ Bedjan, p. 499.
} 
few lines below, ${ }^{54}$ whose acknowledgement constitutes the only effective protection against pride. Here, Isaac points again to the link between negative states, humility, and the acknowledgement of weakness, which, though originally re-elaborated, has strong roots in the Syriac Macarian corpus.

To conclude, what can be said of the relationship between Isaac and 'Macarius'?

At least for the topic and material I examined, it appears that the influence of the Syriac 'Macarius' on Isaac has been considerable. Isaac's distinctive conception of 'weakness' as an original frailty inscribed in the human condition, experienced through the confrontation with negative experiences, and his stress on the necessity to acknowledge it to recognize God's 'otherness' and to discover true humility find remarkable parallels in the Syriac Macarian corpus. From the comparison of these few passages, however, also emerges a picture of Isaac's original interpretation of the words of 'Macarius', stressing the role of suffering and its meaning for personal existence.

If nothing certain can yet be said concerning the form in which Isaac received the Macarian material, something can be said of his approach to the texts.

Isaac is inspired by different writings of the Syriac Macarian corpus, which have different authors and origins, some of which also belong to the Greek corpus, and some others which are proper to the Syriac one. This underlines the fact that for a deeper understanding of Isaac's conceptions, as for Syriac spirituality in general, it is the Syriac versions of the Greek texts which should be central to our research.

Moreover, Isaac approached these writings looking for their meaning for human existence. If we can speak of an influence, this should be understood, primarily, as a dialogue with the texts which helped Isaac to understand his spiritual experience and to make it understandable to others: it is an existential reading rather than a mere borrowing of concepts.

${ }^{54}$ Bedjan, p. 499. 
This approach invites us, contemporary readers, to be open to this sensibility: without abandoning our scientific approaches, we are also encouraged to look at ancient spiritual literature with the ancient reader's eyes, in order to enter his world and to try to discern its meaning. 